\title{
Telaah Atas Konsep Sekolah Pada Buku Laskar Pelangi dan Dunia Tanpa Sekolah
}

\author{
Mintarti, Muslihudin, dan Joko Santoso \\ Dosen Jurusan Sosiologi FISIP Universitas Jenderal Soedirman Purwokerto \\ e-mail: nmintarti@yahoo.co.id
}

\begin{abstract}
Abstrak: Penelitian ini bertujuan untuk mengetahui definisi dan makna konsep sekolah dalam buku Laskar Pelangi (LP) dan Dunia Tanpa Sekolah (DTS) serta mengetahui faktor-faktor yang melatarbelakangi perbedaan cara memaknai konsep itu. Metode yang digunakan dalam penelitian ini yaitu analisis wacana kritis (Critical Discourse Analysis) khususnya model van Dijk. Inti analisisnya menggabungkan tiga dimensi wacana teks, kognisi sosial, dan konteks sosial ke dalam satu kesatuan analisis. Hasil penelitian menunjukkan bahwa terdapat perbedaan pemaknaan konsep "sekolah" pada buku LP dan DTS. Dalam LP, sekolah dimaknai sebagai lembaga yang memerdekakan sementara dalam DTS sekolah dimaknai sebagai lembaga yang memenjarakan. Perbedaan cara pandang di antara keduanya disebabkan oleh perbedaan latar belakang sosial budaya pengarangnya. Andrea berasal dari keluarga miskin dalam masyarakat yang sangat tajam stratifikasi sosialnya, sementara Izza anak dari pasangan guru yang relatif mapan status sosial ekonominya. Di sekolah, keduanya menemukan kenyataan yang berbeda. Andrea bertemu dengan guru-guru yang menginspirasi, yaitu guru yang mampu menerjemahkan kurikulum sedemikian rupa sehingga melekat kuat di benak murid serta dapat membangkitkan semangat untuk keluar dari segala kesulitan. Faktor lain yaitu jumlah murid di kelas Andrea yang karena dipaksa oleh keadaan hanya berjumlah sepuluh orang. Kelas kecil ini justru dapat menciptakan interaksi antar murid yang intens, sehingga suasana belajar menjadi lebih menyenangkan. Sebaliknya, sebagai anak guru yang tidak asing dengan dunia sekolah Izza memiliki pengalaman tidak nyaman di tahun-tahun pertamanya masuk sekolah. Selain itu, hobinya membaca termasuk bacaan-bacaan radikal tentang pendidikan yang tersedia di rumahnya, makin membuatnya sangat membenci sekolah.
\end{abstract}

Kata kunci: sekolah, memerdekakan, dan memenjarakan

Abstact: This research aims is to know definition and school concept meaning on Laskar Pelangi books and Dunia Tanpa Sekolah and also to know the factors which cand be influences of the background of the differences to give deffinition of the concept above. The method of this study is by using model van Dijk Critical Discourse Analysis (CDA). The core of analytical is re-grouping three dymention wacana texs, social cognitive, and social contexs within one analisys. The result of the study shows that there is deffrence in giving meaning on school Pelangi books and Dunia Tanpa Sekolah. On Laskar Pelangi, the meaning of school is the institution give freedom to student to make expression. Otherwise, on Dunia Tanpa Sekolah book is to have jail. The cause of defferences is the deferences of social-economy background. In school, it's the faact that there is defference between them. Andrea meet to

Key words: shool, freedom, and to jail

\section{Pendahuluan}

Novel Laskar Pelangi (LP) tulisan Andrea Hirata yang terbit pertama pada September 2005 sangat fenomenal. Surat kabar harian Republika, 30 Desember 2007 mencatat sebagai berikut.

"Laskar Pelangi tercatat telah laku 200 ribu eksemplar. Jika ditambah dengan novel-novel Andrea yang terbit kemudian, angkanya menjadi lebih besar. Sang Pemimpi laku 120 ribu eksemplar, dan Edensor terjual 25 ribu eksemplar. Jika harga buku Rp 60 ribu, ia dapat royalti 10 persen, maka ia telah mengumpulkan Rp 2,07 miliar dari tiga novelnya itu. Belum royalti yang ia dapat dari edisi Bahasa Melayu yang juga best seller di Malaysia".

Buku itu merupakan memoar yang ditulis sebagai hadiah untuk ibu gurunya semasa ia bersekolah di SD Muhammadiyah pada sekitar tahun 1977-1983. Nama Laskar Pelangi itu sendiri 
adalah julukan yang diberikan oleh NA Muslimah Hafsari Hamid, guru Andrea itu kepada sepuluh murid terakhirnya di SD tersebut (Andrea Hirata, 2007: 160).

Di buku ini, sekolah digambarkan secara paradoksal; di satu sisi secara fisik sangat mengenaskan karena miskinnya namun di sisi lain menjadi tempat yang begitu kaya nilai karena mampu membuatnya bangkit dan termotivasi untuk terus meraih mimpi sehingga ia merasa sangat beruntung karena bersekolah di tempat itu. Berikut ini petikan kisahnya: "Tiba-tiba aku merasa sangat beruntung didaftarkan orang tuaku di sekolah miskin Muhammadiyah. Aku merasa telah terselamatkan karena orang tuaku memilih sebuah sekolah Islam sebagai pendidikan paling dasar bagiku. Aku merasa amat beruntung berada di sini, di tengah orang-orang yang luar biasa ini. Ada keindahan di sekolah Islam melarat ini. Keindahan yang tak 'kan kutukar dengan seribu kemewahan sekolah lain"( Andrea Hirata, 2007: 25).

Gambaran tersebut sangat jauh berkebalikan dengan gambaran muram tentang dunia sekolah seperti yang dipaparkan oleh M.Izza Ahsin dalam buku Dunia Tanpa Sekolah (DTS). Buku ini ditulis oleh seorang anak lelaki berusia 15 tahun yang berani memutuskan untuk keluar dari sebuah SMP favorit di kotanya Salatiga, Jawa Tengah. Meskipun tidak sefenomenal Laskar Pelangi, buku ini telah dua kali dicetak ulang sejak diterbitkan pertama kali di tahun 2007 oleh Read! Publishing House, penerbit dari kelompok Mizan, Bandung.

Keputusan itu bukan keputusan yang mudah di tengah masyarakat yang sangat mengagungkan lembaga persekolahan terlebih bahwa orangtuanya adalah guru. Beban psikologis karena statusnya sebagai keluarga guru, tak pelak menimbulkan konflik hebat di dalam keluarganya. Pertengkaran dan perselisihan pendapat antara orang tua dan anak hampir tiap hari mewarnai hubungan orang tua dan anak. Kompromi untuk mencapai perdamaian juga telah berusaha dilakukan. Namun pada akhirnya Izza tetap teguh pada pendiriannya untuk keluar dari sekolah hanya beberapa bulan menjelang ujian akhirnya di kelas tiga (kelas IX) SMP.

Kata-kata sinis dan pedas berikut ini adalah petikan pertengkaran dengan ayahnya. Kata yang ditulis dengan huruf kapital adalah ekspresi dari kemarahannya: "KOK, PERCAYA SEKALI SIH, SAMA SEKOLAH?!Apa para sarjana D3, S1, dan bahkan $\mathrm{S} 2$ dengan mudah bisa berhasil, begitu?Apa ayah TIDAK MELIHAT KENYATAAN banyak sarjana yang kelimpungan mencari pekerjaan?!Melamar jadi PNS setiap tahun ha...hanya..."Suaraku semakin tercekat oleh tangis di hidung dan tenggorokan."(M.Izza Ahsin, 2007: 90).

Puncak dari amarah Izza adalah ketika dia menulis surat pengunduran dirinya dari sekolah.Walaupun pada akhirnya surat itu tidak jadi dikirimkan kepada kepala sekolah karena setelah dibacanya kembali dinilai terlalu emosional, kalimat-kalimat tajamnya menunjukkan apa yang dia rasakan: "Saya, Muhammad Izza Ahsin Sidqi, dengan tanpa mengurangi rasa hormat pada setiap orang yang mendukung keberlangsungan hidup lembaga formal bernama sekolah, dengan ini menyatakan pengunduran diri dari sekolah ini. Sebuah sekolah yang disebut-sebut sebagai Sekolah Menengah Pertama paling favorit di Salatiga tercinta".(M.Izza Ahsin, 2007:184).

Kedua buku tersebut menarik karena berbicara tentang dunia sekolah dalam sudut pandang yang sangat berbeda. Oleh karena itu, telaah lebih mendalam terhadap konsep sekolah menjadi penting di tengah berbagai isu di bidang pendidikan yang belakangan ini banyak menyedot perhatian publik. Kedua buku yang menjadi fokus kajian penelitian ini lahir dari persentuhan sekaligus keprihatinan kedua penulis buku terhadap dunia sekolah.

Kajian terhadap buku Laskar Pelangi sudah banyak dilakukan karena buku ini sangat fenomenal. Namun sepanjang pelacakan yang telah dilakukan, kajian-kajian tersebut lebih menyentuh pada aspek nilai pendidikan secara umum yang termuat di dalamnya atau yang berkaitan dengan proses pembelajaran di dalam kelas. Dua topik penelitian, yaitu "Analisis Gaya Bahasa dan Nilai Pendidikan Novel Laskar Pelangi" (digilib.uns.ac.id/abstrakpdf) serta "Penelitian Tindakan Kelas" (jeperis.wordpress.com) merupakan contoh penelitian yang diilhami oleh Laskar Pelangi. Akan tetapi, telaah terhadap buku ini yang khusus berbicara tentang institusi formal 
bernama sekolah, terlebih jika disandingkan secara bersamaan dengan buku Dunia Tanpa Sekolah belum pernah dilakukan. Untuk itu, kajian ini menjadi penting dalam upaya mengkritisi plus minus lembaga sekolah yang muara akhirnya adalah pada upaya perbaikan sistem pendidikan di Indonesia.

Berdasarkan uraian dalam bagian pendahuluan, maka rumusan masalah penelitian ini adalah sebagai berikut: 1) Bagaimana konsep sekolah didefinisikan dan dimaknai oleh penulis buku Laskar Pelangi dan Dunia Tanpa Sekolah? dan 2) Mengapa kedua penulis buku tersebut menggambarkan/melihat dengan cara yang berbeda terhadap lembaga sekolah tersebut?

Atas dasar rumusan masalah di atas, maka tujuan penelitian ini adalah untuk mengetahui definisi dan makna konsep sekolah dalam buku Laskar Pelangi (LP) dan Dunia Tanpa Sekolah (DTS) serta mengetahui faktor-faktor yang melatarbelakangi perbedaan cara memaknai konsep itu, yang ada pada penulis kedua buku tersebut.

\section{Kajian Literatur}

\section{Sekolah, Peran Besar Pengaruhnya Terhadap Masyarakat dan Asal-usulnya}

Membaca Laskar Pelangi dan Dunia Tanpa Sekolah berarti membaca pikiran dua orang yang sangat kritis terhadap realitas sosial yang dihadapinya, khususnya realitas pendidikan terutama pendidikan sekolah. Meskipun kedua penulis buku tersebut jauh berbeda dalam usia, masing-masing telah mengalami persentuhan dengan dunia sekolah. Pengalaman itu ternyata meninggalkan kesan yang berbeda; positif dan negatif. Positif karena melalui sekolah motivasi dan semangat untuk keluar dari keterpurukan menjadi timbul, dan sebaliknya negatif karena justru di sekolah pula pengalaman jiwa menjadi terpenjara terjadi juga.

Pertanyaan yang muncul terhadap kenyataan tersebut adalah apa sesungguhnya sekolah itu? Mengapa institusi atau lembaga sosial ini menjadi demikian berpengaruh terhadap kehidupan manusia? Sebelum menjawab pertanyaan ini, ada baiknya dijelaskan terlebih dahulu tentang pengertian institusi atau lembaga sosial. Secara kebahasaan, istilah ini merupakan terjemahan dari bahasa Inggris social institution. Koentjaraningrat dan Soerjono Soekanto mendefinisikan istilah ini sebagai himpunan dari norma-norma dari segala tingkatan yang berkisar pada suatu kebutuhan di dalam kehidupan masyarakat (Sugiyanto: 2002). Ini berarti, semakin banyak kebutuhan masyarakat maka akan semakin banyak pula himpunan normanya. Dengan kata lain, semakin banyak pula lembaga sosial yang ada di dalamnya.

Secara garis besar institusi atau lembagalembaga tersebut dapat dibagi menjadi lembaga politik, ekonomi, agama, keluarga, dan lembaga pendidikan. Sekolah adalah bagian dari lembaga pendidikan. Mengacu pada pengertian lembaga sosial di atas, maka eksistensi sekolah yang tetap ada hingga kini adalah karena masyarakat masih membutuhkannya. Lembaga sekolah di era modern ini bahkan telah menggantikan peran pengasuhan anak yang semula sebagian besar dipegang oleh lembaga keluarga. Jutaan anak di dunia ini, sedari berusia sangat muda setiap hari menghabiskan waktunya di tempat yang bernama sekolah. Citra sekolah sebagai tempat untuk "memintarkan" dan menimba ilmu pun lekat di benak setiap orang, seolah-olah tanpa bersekolah orang tidak mungkin dapat menjadi pintar serta berilmu. Sekolah juga dipahami sebagai keseluruhan sistem mulai dari proses belajar mengajar, peraturan yang mengikat orang-orang yang terlibat di dalamnya, hingga pada kurikulum yang harus diterapkan dalam rangka menimba ilmu tersebut.

Besarnya peran sekolah juga tampak dari posisinya sebagai ukuran maju mundurnya suatu negara. Hasil kerja lembaga ini oleh negaranegara di dunia dijadikan salah satu indikator bagi berkualitas atau tidaknya kehidupan rakyat sebuah negara. Human Development Index (HDI) yang dibuat oleh United Nations Development Programme (UNDP) merupakan wujud nyata dari hal tersebut. Sebagai contoh, Indonesia menurut laporan UNDP tahun 2005 HDI-nya berada para peringkat 110 dari 174 negara. Ini tentu sangat mengejutkan dan memprihatinkan, karena itu berarti daya saing SDM Indonesia untuk memperoleh posisi kerja yang baik sangat rendah (Suyanto: 2006). Padahal satu dasa warsa yang lalu, Mochtar Buchori (1998) telah mengatakan bahwa suatu masyarakat atau bangsa yang tidak memiliki kemampuan bersaing akan punah di era 
globalisasi ini.

Kemampuan untuk berdaya saing tersebut seperti yang dituntut oleh dunia kerja sudah pasti terkait dengan dunia pendidikan. Hanya manusiamanusia yang terdidik di lembaga-lembaga formal itulah yang dapat memasuki dunia kerja. Semakin baik sistem pendidikan di suatu negara, maka akan semakin baik pula daya saing sumber daya manusianya. Ini berarti peran sekolah menjadi sangat besar, sebab ia diharuskan mencetak tenaga kerja yang berkualitas unggul.

Uraian di atas menunjukkan betapa tinggi apresiasi masyarakat terhadap sekolah serta betapa besar peran dan pengaruhnya terhadap kehidupan manusia. Padahal, sebagaimana dikemukakan oleh Topatimasang (1998) jika dilihat dari bahasa aslinya, yakni kata skhole, scola, scolae atau schola (Latin), kata itu secara harfiah berarti "waktu luang" atau "waktu senggang". Makna bahasa ini tampak agak berkebalikan dengan realitas sekolah dewasa ini, yang justru menjadi sesuatu yang serius, tidak main-main, bahkan menjadi wajib. Program "wajib Belajar" seperti yang diterapkan oleh pemerintah Indonesia dan negara-negara lain di dunia menunjukkan bahwa sekolah telah menjadi institusi yang keberadaannya sangat diakui.

Makna awal kata scola, skhole, sebagai "waktu senggang" atau "waktu luang" sebagaimana disebutkan oleh Topatimasang (1998) lebih lanjut, adalah karena pada jaman Yunani kuno yakni jaman dan asal muasal kata tersebut orangorang biasa mengisi waktu luang mereka dengan cara mengunjungi suatu tempat atau seseorang pandai tertentu untuk mempertanyakan dan mempelajari hal-hal yang mereka anggap perlu untuk diketahui. Kegiatan itu mereka sebut dengan kata atau istilah skhole, scola, scolae, atau schola yang keempatnya berarti "waktu luang yang digunakan secara khusus untuk belajar" (leisure devoted to learning).

Apabila dilihat dari asal-usul makna kata sekolah, tampak bahwa ada kemiripan fungsi dengan sekolah yang dikenal di dunia modern sekarang ini. Di masa lalu maupun kini, scolae dan sekolah sama-sama merupakan tempat orang menimba ilmu.atau mempelajari sesuatu. Yang bergeser dari makna tersebut adalah dalam hal "kewajiban" untuk masuk atau terlibat di dalamnya. Jika dahulu scolae hanya merupakan kegiatan pengisi waktu luang, maka sekarang "bersekolah" telah menjadi kegiatan yang wajib diikuti oleh setiap warga masyarakat.

\section{Sekolah sebagai Agen Sosialisasi}

Berbicara tentang fungsi sekolah, tidak diragukan lagi bahwa lembaga ini telah menjalankan beragam fungsi di tengah masyarakat. Selain fungsi manifesnya sebagai tempat menimba ilmu dan mempelajari keterampilan tertentu, sekolah juga punya fungsi laten yaitu sebagai tempat pengasuhan anak di luar keluarga. Selepas usia lima tahun, setiap orang tua akan memasukkan anaknya ke sekolah dasar dan di sekolah itu anak menghabiskan sebagian waktunya tanpa orang tua mereka.

Namun demikian, seperti yang dikatakan Henslin (2007) sejalan dengan makin banyaknya keluarga yang memiliki dua pencari nafkah, pengasuhan anak telah menjadi suatu fungsi manifes. Bermunculannya full day school, yakni sekolah dengan jam belajar yang panjang (sehari penuh) merupakan contoh perluasan fungsi sekolah. Fungsi sebagai tempat pengasuhan ini bahkan telah dimulai semenjak anak berusia 3 tahun, usia resmi pendidikan pra-sekolah yang dipakai sekitar $70 \%$ negara-negara di dunia, atau bahkan ada yang kurang dari itu. Tumbuh suburnya lembaga pendidikan pra-sekolah seperti taman bermain (play group), Taman Kanak-kanak (TK), hingga Taman Penitipan Anak (TPA) menunjukkan betapa orang tua begitu percaya terhadap pengasuhan anak di sekolah. Meski secara resmi taman-taman tersebut belum disebut sebagai "sekolah" atau masih disebut sebagai pra-sekolah, pada kenyataannya tempat itu juga menggunakan kurikulum seperti halnya sekolah formal. Data di seluruh dunia menunjukkan meningkatnya angka partisipasi pendidikan anak usia dini. Laporan yang dibuat UNESCO menyebutkan bahwa jumlah anak yang mendaftar di pendidikan pra-sekolah di dunia melonjak tiga kali lipat pada tiga dekade terakhir, dari 44 juta di pertengahan tahun 1970-an menjadi 124 juta pada tahun 2004 (UNESCO: 2007).

Gambaran tentang angka partisipasi pendidikan pra-sekolah tersebut makin mengukuhkan fungsi sekolah yang secara 
sosiologis makin menguat. Makin kuatnya kepercayaan masyarakat terhadap sekolah tidak terlepas dari fungsi lain sekolah yaitu sebagai tempat sosialisasi sekunder setelah keluarga. Yang dimaksud dengan sosialisasi sebagaimana dikatakan oleh Lawson, dkk. (2000), yaitu "the learning of skills and attitudes in school". Proses belajar tersebut dilakukan oleh individu melalui kurikulum formal (formal curriculum) yang berupa keterampilan dan pengetahuan sebagai bagian dari aktifitas instruksional yang terencana, serta kurikulum tersembunyi (hidden curriculum) yang berupa norma-norma dan nilai-nilai yang diserap individu melalui hubungan sosial dan organisasional di sekolah.

Proses tersebut sebenarnya juga merupakan proses membimbing individu ke dalam dunia sosial. Dalam proses ini, individu belajar tingkah laku, kebiasaan serta pola-pola kebudayaan lainnya, juga keterampilan-keterampilan sosial seperti berbahasa, bergaul, berpakaian, cara makan, dan sebagainya. Walaupun sekolah hanya merupakan salah satu lembaga yang bertanggungjawab atas pendidikan anak, ia memegang peranan penting di dalam proses sosialisasi (Nasution: 1995).

Melalui proses sosialisasi tersebut, anak belajar menyesuaikan diri dengan lingkungan dan masyarakat tempat dia tinggal. Di dalam proses ini banyak nilai yang dianut dan berkembang di sekolah itu. Interaksi dengan guru, teman-teman sesama murid, serta administratur di sekolah merupakan pengalaman yang akan dibawanya hingga ia dewasa. Masih menurut Nasution (1995), hal-hal yang dipelajari anak di sekolah meliputi nilai-nilai yang dianut sekolah, corak kepemimpinan, apakah otokratis atau demokratis, serta hubungan antar-murid, apakah misalnya terutama dipengaruhi oleh suasana persaingan atau kerja sama.

Karena segala sesuatu yang dipelajari seorang individu di sekolah bukan hanya hal-hal yang tercakup di dalam kurikulum formal, maka sangat wajar jika kemudian setiap individu akan menerima pengalaman bersekolah (school experience) yang berbeda-beda. Semua yang dipelajari individu dalam kurikulum formal merupakan hal-hal yang positif mulai dari matematika, bahasa, ilmu pengetahuan alam, sampai pada ilmu agama. Pada sisi ini, sekolah dapat melahirkan orang-orang berilmu pengetahuan sangat bagus sekelas mantar Presiden Habibi.

Namun, hubungan antar-murid maupun guru serta keseluruhan budaya yang berkembang di sekolah itu ternyata tidak selalu positif. Munculnya kasus-kasus tindak kekerasan di sekolah ( bullying) adalah contoh nyata bagaimana sekolah dapat menjadi sarana belajar hal-hal negatif melalui kurikulum tersembunyi (hidden curriculum) yang menyertainya. Barbara Coloroso (2007) mengidentifikasi berbagai tindakan bullying mulai dari meminta uang dengan paksa (memalak), mengolok-olok, merobek baju ataupun buku, perkelahian, bahkan sampai pada pelecehan seksual. Tindakan yang semuanya negatif tersebut dapat berujung pada bunuh diri bagi anak-anak yang mengalami tindak kekerasan itu. Sisi gelap dunia sekolah itu oleh Coloroso digambarkan dengan sangat mengesankan di dalam bagian awal kata pengantar bukunya yang berjudul "Stop Bullying! Memutus Rantai Kekerasan Anak dari Pra-sekolah hingga SMU":

Akan selalu kuingat, dan tak akan pernah kulupa

Senin : uangku diambil

Selasa: namaku diolok-olok

Rabu : seragamku dirobek-robek

Kamis: tubuhku bersimbah darah

Jumat: semua berakhir

Sabtu: kebebasan

Akhir lembaran buku harian Vijay Singh, 13 tahun. Ia ditemukan menggantung diri pada pegangan tangga di rumah pada hari Minggu.

Ilustrasi tersebut makin memperjelas peran sekolah sebagai agen sosialisasi sekunder setelah keluarga yang merupakan agen sosialisasi primer. Melalui sekolah, seorang anak bisa tumbuh menjadi orang seperti mantan Presiden Habibi yang cerdas, namun ia bisa juga menjadi seperti anak yang digambarkan dalam kutipan di atas, kehidupannya berakhir tragis justru setelah ia memasuki lembaga bernama sekolah.

Sebagai agen sosialisasi, itu berarti bahwa sekolah dapat menjadi berwajah ganda. Di satu sisi ia menyosialisasikan hal-hal yang positif, namun pada sisi lainnya hal-hal negatif yang 
disosialisasikan dapat menjadi "pembunuh" bagi anak-anak yang masuk ke dalamnya. Kedua sisi tersebut dapat terjadi karena faktor yang disengaja (melalui kurikulum sekolah yang meskipun disusun dengan maksud positif namun berdampak negatif), dan dapat pula terjadi karena interaksi sosial antar komponen yang ada dalam sekolah tersebut. Sudah pasti yang diharapkan dari lembaga bernama sekolah ini adalah proses sosialisasi yang positif, yang dapat menjadikan anak-anak menjadi generasi penerus masyarakat yang memiliki kreatifitas, tidak terbelenggu dan merasa nyaman saat berada di dalamnya.

\section{Sekolah; Memotivasi atau Memenjarakan?}

Membaca buku Laskar Pelangi dan Dunia Tanpa Sekolah adalah "membaca" sekolah dari dua perspektif. Meski keduanya sama-sama secara kritis mengupas dunia pendidikan, titik tolak kerangka pikir penulisnya berbeda. Berkaitan dengan fungsi sekolah sebagai agen sosialisasi sebagaimana telah diuraikan pada bagian sebelumnya, jelas terlihat adanya kesan positif dan negatif dari para penulisnya. Secara positif sekolah adalah lembaga yang memotivasi Andrea Hirata sebagai seorang individu yang terlibat di dalamnya, untuk bangkit meraih mimpinya. Hal itu terbukti dalam perjalanan hidupnya yang begitu percaya terhadap lembaga pendidikan formal sehingga ia terus berusaha masuk ke dalamnya bahkan sampai ke perguruan tinggi Perancis dan Inggris, dan ia berhasil karena kegigihannya itu. Dari sisi ini, sekolah adalah motivator.

Sebaliknya, dalam Dunia Tanpa Sekolah Izza begitu pesimis dengan dunia sekolah. Sedari duduk di bangku sekolah dasar ia mulai tidak kerasan untuk terus terlibat di dalamnya. Baginya sekolah membelenggunya untuk berkreasi sehingga cita-citanya untuk menjadi penulis besar tidak mungkin dapat diraihnya kalau tetap terus bersekolah. Perasaan terbelenggu dan terpenjara ini terus menggayuti pikirannya, walaupun berbagai bujukan telah ia coba jalankan. Hanya sampai SMP Izza bertahan duduk di sekolah formal. Ia lebih memilih keluar meskipun menanggung berbagai cibiran serta konflik dengan orang tuanya.

Di dalam Sosiologi Pendidikan sebagai bagian dari sosiologi yang khusus berbicara tentang dunia pendidikan, terdapat beberapa perspektif atau cara pandang untuk menjelaskan perbedaan cara melihat sekolah dari dua penulis tersebut. Di antara perspektif yang dapat digunakan adalah perspektif fungsionalis, perspektif konflik, dan perspektif kritis. Menurut Henslin (2007), inti dari aliran fungsionalisme ialah bahwa jika bagianbagian masyarakat bekerja dengan benar, masing-masing bagian tersebut akan memberikan kontribusi pada kesejahteraan dan kestabilan masyarakat. Teori ini berbicara tentang fungsifungsi pendidikan yang terbagi menjadi fungsi manifes dan fungsi laten. Sekolah, dalam perspektif ini berfungsi sebagai tempat untuk mengajarkan pengetahuan dan kete-rampilan, sebagai sarana transmisi budaya dari nilai-nilai sosial, serta menciptakan integrasi sosial dan sebagai sarana penyaluran dalam arti sekolah menentukan pekerjaan yang tepat bagi tiap orang.

Masih menurut Henslin (2007), berbeda dengan para fungsionalis yang berfokus pada manfaat pendidikan, para teoritikus konflik mempelajari bagaimana pendidikan membantu kaum elite untuk mempertahankan dominasi mereka. Mereka menekankan bahwa pendidikan mengabadikan ketidaksetaraan sosial-bahwa pendidikan membantu dipertahankannya pembagian sosial dalam masyarakat dari satu generasi ke generasi berikutnya. Proses tersebut berlangsung melalui kurikulum terselubung (hidden curriculum) yang ada di sekolah, diskriminasi melalui IQ, serta pembiayaan yang tidak setara.

Sementara itu, wacana kritik dalam Sosiologi Pendidikan banyak dilontarkan oleh Paulo Freire (2000). Ia mengkritisi sekolah-sekolah tradisional dan wacana yang dikembangkannya dengan berusaha menciptakan pendidikan yang bermakna, kritis, bersemangat, dan emansipatoris. Munculnya kritik yang radikal terhadap sebagian besar komponen yang terlibat dalam pendidikan dikarenakan para ahli pendidikan tradisional secara umum mengabaikan hal-hal di atas, dan masih menjalankan kebijakan yang paradoksal, yaitu melakukan depolitisasi sekolah dan dalam waktu bersamaan tetap melestarikan dan mengesahkan ideologi kapitalis.

Membaca dua karya yang bercerita tentang sekolah tersebut serta setelah mencermati 
pemikiran para teoritisi fungsional dan konflik, maka meskipun benar bahwa sekolah baik secara sadar maupun tidak telah mengabadikan ketidaksetaraan sosial, seharusnya lembaga ini tetap mampu menjadikan dirinya sebagai lembaga yang memotivasi anak didiknya. Ini berarti, sekolah seharusnya dapat menjadi tempat yang menyenangkan untuk belajar, sebagaimana sejarahnya yang merupakan tempat untuk belajar di waktu senggang (leisure devoted to learning). Suasana yang tercipta dalam waktu senggang tersebut tentu merupakan suasana yang menyenangkan, bukan suasana yang tegang, penuh kekerasan, apalagi membelenggu. Namun demikian, justru dari suasana yang menyenangkan itulah akan dapat tercipta proses belajar yang baik yang memungkinkan anak-anak dapat menyerap berbagai ilmu yang mereka pelajari. dibutuhkan kejelasannya.

Materi penelitian adalah teks berupa dua buah buku, yaitu buku Laskar Pelangi tulisan Andrea Hirata dan buku Dunia Tanpa Sekolah karya M.Izza Ahsin. Analisis terhadap materi penelitian tidak semata-mata terfokus pada apa yang ditulis oleh si penulis sebagai teks, melainkan juga bagaimana suasana jiwa si penulis saat menulis teks tersebut beserta latar belakang sosial budaya tempat si penulis hidup.

\section{Hasil penelitian dan pemahasan Deskripsi Umum Materi Penelitian}

Buku LP, secara fisik termasuk tebal dengan jumlah xviii +534 halaman atau 20,5 cm. Selengkapnya, identitas dan struktur buku dapat dilihat pada tabel 1.

Tabel 1. Identitas dan struktur Buku Laskar Pelangi

\begin{tabular}{|l|l|}
\hline \multicolumn{1}{|c|}{ Identitas Buku } & \multicolumn{1}{c|}{ Struktur Buku } \\
\hline - Tahun terbit pertama kali: 2005 & - Ucapan Terima Kasih. \\
- Hingga tahun 2007 telah 14 kali & - 30 bab pertama tentang kehidupan \\
dicetak ulang. & Ikal (nama kecil Andrea) di masa \\
- Penerbit: Bentang, Yogyakarta. & kecil sampai remaja. \\
& - 4 bab sisanya adalah kisah 12 \\
& tahun kemudian ketika Ikal dewasa. \\
& - Glosarium. \\
& - Tentang Penulis. \\
\hline
\end{tabular}

\section{Metode Penelitian}

Penelitian ini menggunakan metode analisis wacana kritis (Critical Discourse Analysis/CDA). Menurut Fairclough dan Wodak, analisis wacana kritis melihat wacana - pemakaian bahasa dalam tuturan dan tulisan - sebagai bentuk dari praktik sosial. Dari sekian banyak model analisis wacana, model van Dijk adalah model yang paling banyak dipakai. Model ini sering disebut sebagai "kognisi sosial". Inti analisisnya adalah menggabungkan tiga dimensi wacana, yaitu teks, kognisi sosial, dan konteks sosial ke dalam satu kesatuan analisis (Eriyanto: 2008). Penelitian ini juga menggunakan model analisis ini.

Menurut Mulyana (2005), untuk melakukan analisis wacana diperlukan teknik analisis yang bersifat internal dan eksternal. Untuk memahami suatu wacana tertentu tidak seluruh unit analisis harus dikaji. Analisis dapat saja dilakukan terhadap satu atau dua unsur yang memang
Tidak semua bab dalam kisah ini melulu bercerita tentang dunia sekolah. Buku ini juga bercerita tentang kehidupan masyarakat Belitong sebagai setting peristiwanya. Di dalamnya juga diceritakan tentang masa ketika Andrea (Ikal) jatuh cinta kepada gadis Tionghoa anak pemilik toko kelontong tempat SD Muhammadiyah secara rutin biasa membeli kapur tulis. Dapat dikatakan bahwa yang khusus bercerita tentang dunia sekolah, dalam arti banyak bercerita tentang guru dan teman-teman sekelasnya hanya ada di sekitar 4 bab pertama. Selebihnya, Andrea secara detail mengamati kehidupan masyarakat tempatnya tinggal, mulai dari kebiasaan masyarakat Melayu yang suka berdebat, pluralitas masyarakat Belitong, hingga pada persoalan stratifikasi sosial yang begitu tajam yang ada di daerah itu. Mengenai hal ini, Andrea mengakuinya dalam kalimat sebagai berikut: "Sejak kecil aku tertarik menjadi pengamat kehidupan dan sekarang aku 
menemukan kenyataan yang memesona dalam sosiologi lingkungan kami yang ironis". (Andrea Hirata, 2007: 84).

Ironi sebagaimana dimaksud oleh Andrea adalah kenyataan hidup yang dialaminya, yang dia lukiskan sebagai berikut: "Di sini ada sekolahku yang sederhana, para sahabatku yang melarat, orang Melayu yang terabaikan, juga ada orang staf dan sekolah PN mereka yang glamor, serta PN Timah yang gemah ripah dengan Gedong, tembok feodalistisnya. Semua elemen kemudian terjalin dengan gadis tersebut kelak akan menjadi salah satu faktor pendorong yang begitu kuat yang membuatnya termotivasi untuk terus melanjutkan studi, bahkan sampai ke luar negeri.

Di sisi lain, buku DTS secara fisik lebih tipis dibandingkan dengan buku LP. Buku ini terdiri atas 252 halaman dengan ketebalan $19 \mathrm{~cm}$. Secara ringkas, identitas dan struktur buku tersebut dapat disimak pada Tabel 2 .

Tabel 2. Identitas dan struktur buku DTS.

\begin{tabular}{|l|l|}
\hline \multicolumn{1}{|c|}{ Identitas Buku } & \multicolumn{1}{c|}{ Struktur Buku } \\
\hline - Cetakan pertama, April 2007 & - Pengantar. \\
- Cetakan kedua, November 2007. & - Prolog. \\
- Penerbit: Read! Publishing & - Isi buku (cerita) terbagi ke dalam 25 bab \\
House (Kelompok Mizan), Bandung & - Epilog. \\
& - Kelas Pantun. \\
& - Karya Ambisius. \\
& -Read, Write, and Imagine adalah Trilogi! \\
& -Read, Write, and Imagine: \\
& Kisah Nyata yang Diperkuat. \\
& - Tentang Penulis. \\
\hline
\end{tabular}

itu adalah perpustakaan berjalan yang memberiku pengetahuan baru setiap hari". (Andrea Hirata, 2007: 84).

Melalui pernyataannya itu, Andrea telah memberikan secara gamblang latar belakang sosial budaya tempat buku ini ditulis. Demikian pula dengan cerita tentang Ikal yang jatuh cinta dengan gadis Tionghoa pemilik toko tempat ia biasa membeli kapur tulis. Berikut ini adalah contoh kalimat yang dipakai oleh Andrea untuk melukiskan suasana hatinya yang sedang jatuh cinta: "Tapi kami berdua masih terpaku pandang tanpa mampu berkata apa pun, lidahku terasa kelu, mulutku terkunci rapat - lebih tepatnya ternganga. Tak ada satu kata pun yang dapat terlaksana. Aku tak sanggup beranjak. Wanita ini memiliki aura yang melumpuhkan. Tatapan matanya itu mencengkeram hatiku".(Andrea Hirata, 2007: 210).

Kalimat-kalimat tersebut, jika hanya dilihat secara internal sebagai teks yang tidak berkaitan dengan cerita dalam keseluruhan buku $L P$, maka seakan-akan tidak berhubungan dengan persoalan dunia sekolah yang menjadi inti masalah dalam penelitian ini. Namun sebenarnya, bagi si penulis peristiwa jatuh cinta serta interaksi yang
Dalam bagian Pengantar yang diberi sub judul "Dari Orangtua yang Merasa harus Terus Belajar", dapat dibaca pernyataan orang tua Izza dalam hal ini ayahnya, yang menceritakan sekilas pengalamannya memiliki anak yang memberontak seperti Izza. Baginya, pemberontakan Izza merupakan hal yang berat sehingga menimbulkan konflik dan suasana tidak enak dalam keluarganya. Sebagai seorang guru yang - seperti dikatakannya sendiri - "selalu mencari wawasan baru tentang pendidikan", ia kaget ketika anaknya ingin keluar dari sekolah dengan alasan merasa terpenjara di sekolah. Kekagetannya lalu muncul dalam bentuk kemarahan luar biasa. Ia mengungkapkan hal tersebut dalam kalimat seperti di bawah ini: "Izza, anak pertama saya, dengan berani meminta izin untuk keluar dari sekolah dengan alasan sekolah itu memenjarakan pikiran, membelenggu kreativitas, dan akan membuat manusia jadi pembebek. Saya marah, dan kemarahan itu telah melampaui batas kewajaran". ( M.Izza Ahsin, 2007: 6).

Selain di bagian Pengantar, ayah Izza juga menorehkan catatannya untuk bagian Tentang Penulis. Di bagian ini ia mendeskripsikan secara singkat tentang diri Izza. Anak lelakinya ini 
dikatakannya sebagai anak yang sejak kecil punya hobi membaca sekaligus menulis, dan telah menghasilkan beberapa karya meski tidak diterbitkan. Berikut ini cuplikannya: "Kegiatan membaca telah menjadi kesukaannya; mulai bacaan komik, buku tentang tokoh sukses, cerita fiksi, nonfiksi, sains, sejarah, buku-buku agama, sampai buku-buku tentang pendidikan. Kegiatan itu dimulai sejak dia masih duduk di bangku Sekolah Dasar. Kegiatan membaca tersebut membuahkan hobi lain, yaitu menulis. Saat SD, dia telah menyelesaikan sekian kisah yang terdokumentasikan dalam lima buku tebal". (M.Izza Ahsin, 2007: 246).

Di luar kedua bagian tersebut, bab-bab dalam buku ini sepenuhnya menceritakan kisah tentang perjuangan sang penulis untuk keluar dari sekolah. Meski tidak mudah, pada akhirnya keinginan untuk lepas dari lembaga formal yang dia rasakan membelenggu itu akhirnya berhasil juga.

\section{Membaca Makna Sekolah; Antara "Memerdekakan" dan "Memenjarakan" Andrea Hirata (Laskar Pelangi)}

Sekolah yang dalam bahasa aslinya yakni kata skhole, scola, scolae atau schola (Latin) secara harfiah artinya adalah "waktu luang" atau "waktu senggang"(Topatimasang: 1998). Menilik arti harfiahnya sangat jauh berbeda dengan kenyataan sekolah di dunia sekarang yang telah menjadi institusi "wajib". Pentingnya sekolah di dunia modern bahkan telah menjadikannya salah satu dari empat agen sosialisasi setelah keluarga, teman bermain, dan media massa (Sunarto: 2000).

Dalam LP, kata "sekolah" termasuk berbagai kata turunannya yang dipakai dengan awalan dan akhiran, serta sebagai singkatan seperti kata "bersekolah", "menyekolahkan", "Sekolah Dasar (SD)", "Sekolah Menengah Pertama (SMP)" disebut sebanyak 356 kali. Sekolah ini merupakan sekolah dalam strata terendah dari struktur sosial dalam dunia pendidikan di Belitong. Sebagai sekolah miskin yang tidak mempunyai fasilitas penunjang belajar, ternyata sekolah ini mampu melahirkan murid-murid yang memiliki motivasi yang tinggi untuk belajar yang tinggi dan berani bercita-cita.
Andrea, anak karyawan rendahan di PN Timah beserta sembilan teman sekelasnya yang juga datang dari keluarga miskin, harus bersekolah di Perguruan Muhammadiyah (SD dan SMP). Walaupun di Belitong terdapat beberapa kategori sekolah, kemiskinan dan stratifikasi sosial masyarakatnya memaksa mereka untuk hanya dapat mendaftar di sekolah paling miskin itu. Ada tiga penyebab orang tua mereka memasukkan anaknya di sekolah itu, seperti penuturannya berikut ini: "Pertama, karena sekolah Muhammadiyah tidak menetapkan iuran dalam bentuk apa pun, para orang tua hanya menyumbang semampu mereka. Kedua, karena firasat, anak-anak mereka dianggap memiliki karakter yang mudah disesatkan iblis sehingga sejak usia muda harus mendapat pendadaran Islam yang tangguh. Ketiga, karena anaknya memang tak diterima di sekolah manapun" (Andrea Hirata, 2007: 4).

Mereka memaknai sekolah sebagai tempat yang dapat mengeluarkan dari kebodohan serta membentuk anak menjadi manusia yang berakhlak melalui pendidikan agama yang ditawarkan sekolah itu. Dapat dikatakan bahwa sekolah dianggap sebagai lembaga yang memerdekakan. Berikut ini penuturan selanjutnya: "Menyekolahkan anak berarti mengikatkan diri pada biaya selama belasan tahun dan hal itu bukan perkara gampang bagi keluarga kami....Pagi ini mereka terpaksa berada di sekolah ini untuk menghindarkan diri dari celaan aparat desa karena tak menyekolahkan anak atau sebagai orang yang terjebak tuntutan zaman baru, tuntutan memerdekakan anak dari buta huruf" (Andrea Hirata, 2007: 3).

Terkait dengan pelajaran yang diterima anak di sekolah, Robert Dreeben (dalam Sunarto: 2000) berpendapat bahwa yang dipelajari anak di sekolah - di samping membaca, menulis, dan berhitung - adalah aturan mengenai kemandirian (independence), prestasi (achievement), universalisme (universalism), dan spesitifitas (specificity). Pemikiran Dreeben ini dipengaruhi oleh dikotomi yang dikembangkan oleh Talcott Parsons - misalnya antara ascription dan acheivement, particularism dan universalism, diffusseness dan specificity.

Dalam kasus Andrea, sekolah dapat menjadi 
lembaga yang memerdekakan dan memotivasi anak didiknya disebabkan oleh beberapa hal. Berikut ini adalah hasil analisis berdasarkan wacana yang diteliti dalam buku $L P$ :

Faktor guru (Pak Harfan dan Bu Muslimah) yang pandai memotivasi "...kami sering mengeluh mengapa sekolah kami tak seperti sekolahsekolah lain. Terutama atap sekolah yang bocor dan sangat menyusahkan saat musim hujan. Beliau tak menanggapi keluhan itu tapi mengeluarkan sebuah buku berbahasa Belanda dan memperlihatkan sebuah gambar..."Inilah sel Pak Karno di sebuah penjara di Bandung, di sini beliau menjalani hukuman dan setiap hari belajar, setiap waktu membaca buku. Beliau adalah salah satu orang tercerdas yang pernah dimiliki bangsa ini", beliau tak melanjutkan ceritanya. Kami tersihir dalam senyap. Mulai saat itu kami tak pernah lagi memprotes keadaan sekolah kami" (Andrea Hirata, 2007: 31). "Beliau menorehkan benang merah kebenaran hidup yang sederhana melalui kata-katanya yang ringan namun bertenaga seumpama titik-titik air hujan. Beliau mengobarkan semangat kami untuk belajar dan membuat kami tercengang dengan petuahnya tentang keberanian pantang menyerah melawan kesulitan apa pun. Pak Harfan memberi kami pelajaran pertama tentang keteguhan pendirian, tentang ketekunan, tentang keinginan kuat untuk mencapai cita-cita" (Andrea Hirata, 2007: 24).

Apabila diringkas, kedua tokoh guru dalam kisah ini dapat dilihat seperti dalam tabel 3.

\section{Faktor interaksi antar murid yang intens}

Kelas tempat Andrea bersekolah merupakan kelas dengan jumlah murid yang kecil atau sedikit, yakni hanya ada sepuluh anak (termasuk Andrea/Ikal). Jumlah sepuluh itu pun merupakan batas minimum, jika sekolah Muhammadiyah tidak ingin ditutup oleh pemerintah. Hal itu terungkap dari penuturan Andrea yang menceritakan kecemasannya saat pertama kali mendaftar di sekolah itu ditemani ayahnya: "Guru-guru sederhana ini berada dalam situasi genting karena Pengawas Sekolah dari Dedikbud Sumsel telah memperingatkan bahwa jika SD Muhammadiyah hanya mendapat murid baru kurang dari sepuluh orang maka sekolah paling tua di Belitong ini harus ditutup" (Andrea Hirata, 2007: 4-5).

Sembilan dari sepuluh murid (tanpa Andrea/ Ikal) dan karakternya di dalam cerita ini, dapat diringkas dalam Tabel 4.

Tabel 3. Karakteristik tokoh guru

\begin{tabular}{|c|c|c|}
\hline No. & Nama & Karakter \\
\hline 1. & $\begin{array}{l}\text { Harfan } \\
\text { Efendy Noor }\end{array}$ & $\begin{array}{l}\text { - Telah puluhan tahun mengabdi di sekolah Muhammadiyah tanpa } \\
\text { imbalan apa pun demi motif syiar Islam (halaman 21). } \\
\text { - Menghidupi keluarga dari sebidang kebun palawija di pekarangan } \\
\text { rumahnya. } \\
\text { - } \quad \text { Pandai bercerita (halaman 22). } \\
\text { - Tampak amat bahagia menghadapi murid, tipikal "guru"1 yang } \\
\text { sesungguhnya. } \\
\text { - } \quad \text { Pandai memotivasi (halaman 24). } \\
\text { - Dapat meyakinkan bahwa hidup bisa demikian bahagia dalam } \\
\text { keterbatasan jika dimaknai dengan keikhlasan berkorban untuk } \\
\text { sesama (halaman 24). "Hiduplah untuk memberi sebanyak- } \\
\text { banyaknya, bukan untuk menerima sebanyak-banyaknya". }\end{array}$ \\
\hline 2. & $\begin{array}{l}\text { Muslimah } \\
\text { Hafsari } \\
\text { Hamid }\end{array}$ & $\begin{array}{l}\text { - } \quad \text { Seorang tamatan Sekolah Kepandaian Putri (SKP). } \\
\text { - } \quad \text { Mengajar semua mata pelajaran karena sekolah kekurangan guru, } \\
\text { menyusun sendiri silabus pelajaran budi pekerti. } \\
\text { - Menerima jahitan untuk mencari nafkah, menopang hidup dirinya } \\
\text { dan adik-adiknya. } \\
\text { - Guru yang pandai, karismatik dan memiliki pandangan jauh ke } \\
\text { depan. } \\
\text { - Pandai memotivasi (semuanya termuat di halaman } 30-31 \text { ). } \\
\text { - Pandai menciptakan atmosfer kelas yang merangsang murid untuk } \\
\text { berbicara (halaman } 110) \text {. }\end{array}$ \\
\hline
\end{tabular}


Tabel 4 Karakter tokoh murid (anggota Laskar Pelangi)

\begin{tabular}{|c|c|c|}
\hline No. & Nama & Karakter \\
\hline 1. & Syahdan & $\begin{array}{ll}\text { - } & \text { Anak nelayan, bekerja sambilan sebagai tukang dempul perahu. } \\
\text { - } & \text { Berpembawaan ceria. } \\
\text { - } & \text { Bercita-cita menjadi aktor. }\end{array}$ \\
\hline 2. & A Kiong & $\begin{array}{ll}\text { - } & \text { Anak seorang Tiong Hoa miskin, ayahnya menggarap kebun sawi. } \\
\text { - } & \text { Naif, tidak peduli, penolong dan ramah. } \\
\text { - } & \text { Tidak terlalu pintar tetapi setia kawan. } \\
\text { - } & \text { Bercita-cita menjadi kapten kapal. }\end{array}$ \\
\hline 3. & Kucai & $\begin{array}{ll}\text { - } & \text { Ketua kelas. } \\
\text { - } & \text { Bodoh ("lemot"), menderita miopia (rabun jauh). } \\
\text { - } \quad \text { Optimis, tidak minder, punya kepribadian populis, oportunis, } \\
\text { bermulut besar, banyak teori dan sok tahu. } \\
\text { - } \quad \text { Punya network yang luas dan pintar bermain kata-kata. } \\
\text { - } \quad \text { Bercita-cita menjadi anggota dewan (wakil rakyat). }\end{array}$ \\
\hline 4. & Trapani & $\begin{array}{l}\text { - } \quad \text { Rapi, perfeksionis, tak bicara jika tak perlu, jika bicara } \\
\text { menggunakan kata-kata yang dipilih dengan baik, santun, sangat } \\
\text { berbakti kepada orang tua khususnya ibunya. } \\
\text { - } \quad \text { Ayahnya adalah operator vessel board dan tukang sirine di PN. } \\
\text { - } \quad \text { Pendiam tetapi pintar. } \\
\text { - } \quad \text { Bercita-cita menjadi guru yang mengajar di daerah terpencil. }\end{array}$ \\
\hline 5. & Sahara & $\begin{array}{l}\text { - } \quad \text { Satu-satunya perempuan di kelas. } \\
\text { - } \quad \text { Cantik, ramping, berjilbab. } \\
\text { - } \quad \text { Penuh perhatian tetapi kepala batu dan temperamental, pintar, } \\
\text { selalu bertengkar dengan A Kiong. } \\
\text { - } \quad \text { Skeptis, susah diyakinkan, tidak mudah dibuat terkesan, jujur, } \\
\text { menghargai kebenaran. } \\
\text { - } \quad \text { Bercita-cita menjadi pejuang hak-hak asasi wanita. }\end{array}$ \\
\hline 6. & Harun & $\begin{array}{l}\text { - Santun, pendiam, murang senyum, teman yang menyenangkan, } \\
\text { pakaian selalu rapi. } \\
\text { - } \quad \text { Punya hobi mengunyah permen asam jawa. } \\
\text { - Sama sekali tidak bisa menangkap pelajaran membaca dan } \\
\text { - } \quad \text { Senulis, sehingga tidak punya rapor. } \\
\text { - } \quad \text { Bercita-cita menjadi Trapani. }\end{array}$ \\
\hline 7. & $\begin{array}{l}\text { Borek } \\
\text { (Samson) }\end{array}$ & $\begin{array}{l}\text { - } \quad \text { Prestasi sekolahnya biasa-biasa saja. } \\
\text { - } \quad \text { Terobsesi pada body building dan tergila-gila dengan citra cowok } \\
\text { macho. } \\
\text { - } \quad \text { Bercita-cita menjadi tukang sobek karcis dan sekuriti bioskop. }\end{array}$ \\
\hline 8. & Lintang & 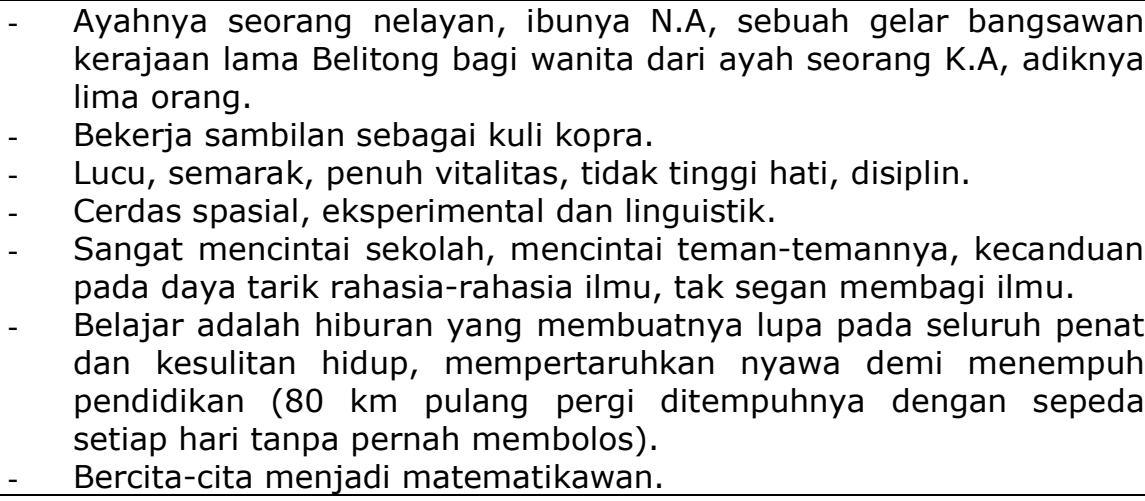 \\
\hline 9. & Mahar & $\begin{array}{l}\text { - } \quad \text { Ayahnya telah lama sakit-sakitan. } \\
\text { - } \quad \text { Bekerja sampingan sebagai pesuruh tukang parut kelapa. } \\
\text { - } \quad \text { Berbakat seni, penggemar berat dongeng-dongeng yang tidak } \\
\text { masuk akal dan segala sesuatu yang berbau paranormal. } \\
\text { - Bercita-cita menjadi sutradara dan penasihat spiritual, } \\
\text { hypnotherapist. }\end{array}$ \\
\hline
\end{tabular}


Kecilnya jumlah murid dalam kelas itu memungkinkan terjadinya sebuah kelompok yang di dalam sosiologi sering disebut sebagai kelompok primer, yaitu suatu kelompok di mana kita dapat mengenal orang lain sebagai suatu pribadi secara akrab (Horton dan Hunt:2006). Bukti bahwa pengenalan terhadap kawan dapat demikian intens, dapat dilihat dari karakteristik pribadi masing-masing anak yang diuraikan oleh Andrea seperti dalam tabel 4 tersebut. Penulis buku ini dapat mengingat dengan rinci sifat atau kepribadian dari semua teman sekelasnya itu.

\section{Faktor kurikulum sekolah}

Di dalam setiap sekolah Muhammadiyah, mata pelajaran kemuhammadiyahan merupakan pelajaran yang wajib diikuti oleh setiap siswanya. Pelajaran itu pada intinya berisi tentang nilai-nilai keislaman sebagaimana dipahami oleh K.H. Ahmad Dahlan, pendiri Muhammadiyah. Pelajaran ini masuk ke dalam kurikulum sekolah Muhammadiyah dan menjadi ciri khas sekolah itu. Mereka memiliki guru semacam Bu Mus dan Pak Harfan yang membuat ruh mata pelajaran itu merasuk menjadi fondasi yang kuat dalam membentuk nilainilai moral dalam menghadapi kerasnya hidup. Berkaitan dengan hal ini Andrea menulis: "Di sekolah ini aku memahami arti keikhlasan, perjuangan, dan integritas. Lebih dari itu, perintis perguruan ini telah mewariskan pelajaran yang amat berharga tentang ide-ide besar Islam yang mulia, keberanian untuk merealisasi ide itu meskipun tak putus-putus dirundung kesulitan, dan konsep menjalani hidup dengan gagasan manfaat sebesar-besarnya untuk orang lain melalui pengorbanan tanpa pamrih" (Andrea Hirata, 2007: 85).

Menurut T. Raka Joni (dalam Sindhunata: 2002), berdasarkan keberdampakannya kepada siswa, terdapat 5 tataran kurikulum, yaitu (a) kurikulum ideal, (b) kurikulum formal, (c) kurikulum instruksional, (d) kurikulum operasional, (e) kurikulum eksperimental. Kurikulum yang diterapkan di sekolah-sekolah adalah kurikulum formal, yaitu kurikulum yang akhirnya di-sanction oleh yang berkewenangn dan kemudian ditampilkan sebagai dukumen resmi kurikulum. Di negara kita, kurikulum formal itu terdiri dari tujuan, materi yang merupakan bagian terbesar, serta pedoman umum pelaksanaan. Apa yang dipraktikkan oleh Bu Musliman dan Pak Harfan dalam cerita ini merupakan implementasi dari kurikulum instruksional yakni terjemahan dari kurikulum formal menjadi seperangkat skenario pembelajaran. Sementara itu, makna dari pengalaman belajar yang terhayati oleh para anggota Laskar Pelangi adalah kurikulum eksperensial yaitu dampak dalam bentuk perubahan cara berpikir dan cara bertindak para siswa.

\section{Faktor buku "Seandainya Mereka Bisa Bicara" karya Herriot}

Faktor ini sebenarnya tidak secara langsung berkaitan dengan sekolah. Buku yang sangat menginspirasi Andrea dan selalu dibacanya saat ia sedih itu merupakan pemberian dari A Ling, gadis Tiong Hoa anak pemilik toko kelontong yang ditaksirnya. Ketika A Ling harus meninggalkan Belitong menuju Jakarta mengikuti pamannya, ia memberi Ikal kenang-kenangan berupa buku tersebut.

Setelah dewasa, Andrea menyadari bahwa buku itu begitu berpengaruh dalam kehidupannya. Berikut ini pengakuannya: "...aku segera menyadari bahwa seluruh kehidupan dewasaku telah terinspirasi oleh buku kumal yang selalu kubawa ke mana-mana itu. Dulu ketika frustrasi karena berpisah dengan A Ling maka pesona Desa Edensor, Taman Daffodil dan jalan pasar berlandaskan batu-batu bulat, serta hamparan sabana di bukit-bukit Derbyshire telah menghiburku. Kemudian pada masa dewasa ini ketika kehidupanku di Bogor berada pada titik terendah aku perlahan-lahan bangkit juga karena semangat yang dipancarkan oleh Herriot, sang tokoh utama buku itu" (Andrea Hirata, 2007: 455 - 479).

\section{Izza Ahsin (Dunia Tanpa Sekolah)}

Meski buku ini terasa kurang "menggigit" seperti halnya LP yang penulisnya sudah lebih kaya akan pengalaman hidup, keberanian Izza untuk memberontak terhadap dunia sekolah yang sudah begitu mapan dalam masyarakat merupakan kejadian langka dan karenanya menjadi istimewa. Dalam buku ini, kata "sekolah" dan berbagai kata turunannya disebut sebanyak 330 kali. 
Izza adalah anak dari pasangan guru. Ayahnya mengajar kimia di sebuah SMA sedangkan ibunya adalah guru Taman Kanakkanak (TK). Sebagai anak guru, dunia pendidikan tidak asing lagi baginya. Semenjak kecil ia terbiasa mengikuti ibunya ke TK tempatnya mengajar. Tentang orangtuanya, ia menulis: "Ayah termasuk orang yang sangat dihormati dan jadi panutan...Ibu dikenal sebagai guru TK yang cerdas. Seperti ayah, ibu juga seorang sarjana dan pernah beberapa kali memenangi lomba guru berprestasi tingkat nasional dengan berbagai makalahnya tentang pendidikan".

Membahasakan dirinya dengan sebutan "aku", Izza menjadi tokoh sentral cerita. Dapat dikatakan tidak ada tokoh lain yang mempunyai peran cukup banyak dalam cerita ini. Meskipun di buku ini juga diceritakan tentang tokoh ayah dan ibu, kesan bahwa keduanya hanya merupakan "peran pembantu" terasa sekali. Dengan kata lain, buku ini lebih merupakan curahan hati dan pergolakan batin penulisnya berhadapan dengan tembok tebal sekolah yang dia rasakan mengungkung dan memenjarakan. Secara garis besar, Izza memliki karakter pada Tabel 5 . suntik. Aku sampai melompat lewat jendela saking takutnya dalam acara imunisasi masuk sekolah...Waktu kelas dua aku harus menghadapi guru yang paling ditakuti murid. Selain galak dan ceplas-ceplos, juga terkenal pilih kasih. Korban utamanya adalah para murid kelas dua yang tidak mengikuti lesnya. Bukan satu atau dua kali saja dia mengataiku dengan goblok, dungu, atau semacamnya".

Puncak kenyamanan sebagai murid SD dirasakannya ketika ia duduk di kelas lima dan enam. Ia mengatakan: "Puncak dari segala kenyamanan bersekolah ini aku rasakan di kelas lima dan enam. Waktu itu aku sangat terkenal sebagai tokoh CC, singkatan Cerdas Cermat, karena kegemaranku membaca apa saja. Ini merupakan terobosan baru dalam kegiatan belajar mengajar yang dipraktikkan oleh Bu Indri, guru IPS sekaligus guru terbaik yang pernah aku temukan selama aku bersekolah formal". (M.Izza Ahsin, 2007: 18).

Meski demikian, masa SMP tidak membuatnya makin menyukai sekolah. Sejalan dengan bertambahnya usia, ia menjadi makin kritis terhadap lingkungan sekolahnya. Kebosanannya

Tabel 5. Karakter tokoh dalam buku DTS

\begin{tabular}{|c|c|}
\hline No. & Karakter \\
\hline $\begin{array}{l}1 . \\
2 . \\
3 . \\
4 . \\
5 .\end{array}$ & $\begin{array}{l}\text { Berkemauan keras, pantang menyerah (halaman } 79) \rightarrow \text { "Aku terus bersikeras dan } \\
\text { bertekad". } \\
\text { Sangat gemar membaca. (hampir di sepanjang halaman) } \\
\text { Punya hobi menulis, bercita-cita menjadi penulis besar (sepanjang halaman). } \\
\text { Peka/perasa (halaman } 173) \rightarrow \text { "Izza itu orangnya perasa sekali, Iho," kata ibu. } \\
\text { Pendiam (halaman 176) } \rightarrow \text { "Izza itu benar-benar anak pendiam," kata Betty. }\end{array}$ \\
\hline
\end{tabular}

Pertanyaannya kemudian adalah mengapa ia merasa terkekang dan terpenjara di sekolah? Berdasarkan analisis, ternyata Izza telah memiliki gambaran tidak menyenangkan tentang dunia sekolah sedari ia masih TK. Berikut ini catatannya: "Walau aku tidak terlalu ingat, orangtuaku berkata kalau aku pernah ngompol karena dipaksa tampil di kelas. Aku juga pernah menangis lama sekali sampai orangtuaku datang menjemput" ( M.Izza Ahsin, 2007: 17-18). "Memasuki masa-masa awal Sekolah Dasar (SD) lebih tidak menyenangkan lagi..Waktu kelas satu aku pernah kabur dari kelas karena takut jarum itu dapat dibaca pada kutipan berikut: "Kalau bukan karena kegiatan bersama teman-teman setelah pulang sekolah, aku mungkin akan merasa sia-sia telah menghabiskan delapan jam di sekolah" (M.Izza Ahsin, 2007: 40).

Halaman-halaman berikutnya hampir dipenuhi dengan kalimat-kalimat yang mengggambarkan kejenuhannya terus menerus menghabiskan waktu di sekolah. Ia bercita-cita menjadi penulis besar, dan menurutnya untuk itu ia tidak harus menempuh pendidikan di sekolah formal. Kenyataan bahwa orangtuanya tidak mendukung keinginannya untuk keluar dari sekolah membuat 
Izza makin merasa sendirian. Setelah melalui perenungan yang panjang serta usaha-usaha untuk saling berkompromi yang gagal, pada akhirnya orangtua Izza mengabulkan keinginan anaknya untuk keluar dari sekolah: "Sekarang kami telah memberimu kebebasan untuk memilih... Tetapi ada syaratnya. Kamu harus membaca buku-buku yang ayah minta. Kamu harus membagi waktu antara belajar agama dan sastra. Pendeknya, ini adalah kurikulum yang ayah buat" (M.Izza Ahsin, 2007: 160-161).

Pemikiran yang begitu kritis dan revolusioner itu dalam banyak hal dipengaruhi oleh bacaanbacaan yang sejak kecil sudah dilahapnya. Ia sangat suka membaca kisah-kisah biografi para tokoh dunia. Thomas Alva Edison, Michael Faraday, James Watt, John Dalton mengajarkannya bahwa menjadi guru bagi diri sendiri lebih baik daripada belajar dengan guru yang tidak akan pernah mungkin mengerti. Begitu pula tokoh-tokoh di berbagai bidang lain. Di bidang sastra, ia mengenal Mark Twain yang mengatakan tak kan pernah dalam hidupnya dia membiarkan sekolah mencampuri pendidikannya, Rabindranath Tagore yang berkata bahwa sekolah itu adalah siksaan yang tak tertahankan, dan Bernard Shaw yang melarang karya-karyanya diajarkan di sekolah. Masih banyak tokoh lain yang disebutkannya dan itu memengaruhi cara pandangnya terhadap sekolah. (M.Izza Ahsin, 2007: 164-165).

\section{Guru Kunci Utama Dunia Sekolah}

Berdasarkan analisis terhadap dua buku itu, terdapat dua pandangan berbeda tentang sekolah. Pertama adalah yang mendukung dan berpandangan positif, dan kedua adalah yang menentang. Sudut pandang pertama melihat sekolah sebagai lembaga yang memerdekakan serta dapat memotivasi, sebaliknya sudut pandang kedua menganggap bahwa sekolah adalah lembaga yang memenjarakan dan membelenggu kreativitas murid. Dalam kata-kata Roem Topatimasang (1998) disebut bahwa sekolah sudah terlalu sering disesali, tapi pada saat bersamaan sekaligus juga amat didambakan.

Dalam hal ini, peneliti sendiri tidak ingin jatuh pada salah satu sudut pandang secara ekstrim. Masing-masing pandangan ada sisi positif dan negatifnya. Di satu sisi meski bukan satu-satunya faktor, lembaga sekolah dapat menjadi sarana bagi individu untuk mengalami mobilitas sosial ke atas. Nasution (1995) menyatakan, pendidikan membuka kemungkinan adanya mobilitas sosial. Berkat pendidikan seseorang dapat meningkat dalam status sosialnya. Pada sisi lain, sekolah formal membuat anak didik menjadi "terkekang" karena mereka harus mematuhi berbagai aturan atas nama disiplin sekolah, serta mempelajari banyak hal yang sudah disusun dalam kurikulum. Pengalaman Izza telah menunjukkan hal terakhir ini.

Namun demikian, meniadakan sama sekali sekolah formal merupakan hal yang hampir dapat dikatakan mustahil. Hal ini karena sekolah telah menjadi suatu institusi yang mengakar kuat di dalam masyarakat, sehingga bukan hal mudah untuk menghapusnya dari kehidupan masyarakat. Topatimasang (1998) menyatakan, sekolah memang telah terinternalisasikan sedemikian rupa dalam seluruh bagian kehidupan keseharian kita, melalui suatu proses sejarah yang panjang dan lama, yang sedemikian berpengaruh terhadap kehidupan perseorangan dan perkauman kita, menjadi suatu imperatif budaya, semacam gejala "ketaksadaran kolektif".

Karena hampir mustahil untuk dihapus dari kehidupan masyarakat, maka yang perlu dilakukan adalah berusaha menambal yang sobek, memperbaiki yang rusak, ataupun mengganti yang sudah usang dari sistem persekolahan. Dalam hal ini, sebenarnya ada satu kunci yang dapat menjadi variabel antara, yakni faktor guru. Banyak orang terbukti begitu terkesan dengan pengalaman bersekolah karena telah berinteraksi dengan guru yang menginspirasi. Misalnya, Rizali dkk (2009) menulis: "Pada pertengahan 1960, kulihat ibu guruku di TK IWKA (Ikatan Wanita Kereta Api) Kota Malang sebagai perempuan paling cantik dan baik hati sesudah ibuku. Aku diajaknya ikut lomba menyanyi di RRI Malang yang sekarang menjadi hotel terbaik di sana. Mengapa aku begitu senang dengan ibu guruku itu? Sebab, kurasa saat itu dia sangat baik hati dan memberiku dorongan untuk berani melakukan sesuatu yang baru, tidak ada kata salah atau benar. Saat itu lomba menyanyi, karena suaraku tidak terhitung istimewa, aku pun kalah. Bu Guru tidak kecewa, bahkan tetap 
memperlakukan aku dengan baik - bahkan lebih baik karena sudah berani ikut".

Dari dua buku yang menjadi materi penelitian ini pun sebenarnya ada satu titik temu di antara kedua penulis. Mereka mengakui bahwa guru merupakan figur paling penting dalam sistem pendidikan. Hanya guru yang inspiratif dan pandai merengkuh hati murid-muridnyalah yang akan terus hidup dalam hati dan pikiran murid. Bahkan Izza yang begitu membenci sekolah pun tetap mengenang salah seorang gurunya sebagai orang yang telah mampu menumbuhkan kreativitas murid-muridnya. Ia mencatat: "....Ini merupakan terobosan baru dalam kegiatan belajar mengajar yang dipraktikkan oleh Bu Indri, guru IPS sekaligus guru terbaik yang pernah aku temukan selama aku bersekolah formal...Bu Indri - tidak seperti guruku di kelas dua - sejak saat itu selalu menganggapku sebagai anak yang patut dicontoh, bukan anak goblok yang tidak bisa mengerjakan soal matematika" (M.Izza Ahsin, 2007: 18 dan 20).

Di era sekarang ketika paham materialisme dan hedonisme mulai mengikis jiwa remaja pun, peran guru menjadi sangat penting. Darmaningtyas (2005) melukiskan sebagai berikut: "...Jelas bahwa fungsi guru pada masa sekarang dan mendatang adalah mengisi ruang-ruang kosong yang menjadi jarak antara realitas empiris dengan yang diidealkan...tugas ini memang berat, tapi mau tidak mau harus dijalankan oleh guru agar mereka tidak kehilangan perannya. Kompleksitas persoalan yang dihadapi remaja serta kecenderungan Ipoleksosbud-Hankam yang makin tidak terduga, menuntut kearifan tersendiri dari guru agar bisa mengambil posisi secara tepat".

Guru-guru seperti yang digambarkan itu adalah "Great Teachers" yang memberi inspirasi dan lebih dari sekadar gurusuper yang mampu mendemonstrasikan keterampilannya sebagai guru (Rizali, dkk: 2009).

\section{Simpulan dan Saran Simpulan}

Berdasarkan hasil penelitian dan pembahasan, dapat ditarik beberapa kesimpulan sebagai berikut. Pertama, dalam buku LP, sekolah didefinisikan dan dimaknai sebagai institusi sosial yang memerdekakan walaupun secara fisik miskin. Ada beberapa faktor yang membuatnya berpandangan seperti itu, yaitu faktor guru yang pandai memotivasi, faktor interaksi yang intens antar murid yang memungkinkan tumbuhnya persahabatan, faktor kurikulum yang menanamkan nilai-nilai untuk mampu keluar dari segala kesulitan, dan faktor buku cerita karya Herriot yang mampu membangkitkan semangat ketika jiwanya sedang gundah. Dalam buku DTS, sekolah didefinisikan dan dimaknai sebagai lembaga yang memenjarakan. Pandangan ini muncul sebagai dampak dari kegemaran penulisnya (Izza) membaca buku-buku, khususnya karya penulispenulis yang kritis terhadap pendidikan sekolah. Pembacaan terhadap tulisan-tulisan itu kemudian dihubungkannya dengan pengalaman-pengalaman buruknya di saat-saat awal bersentuhan dengan dunia sekolah. Kedua, perbedaan cara pandang di antara keduanya disebabkan oleh latar belakang sosial budaya yang berbeda. Andrea berasal dari keluarga miskin tidak berpendidikan dan hidup di tengah masyarakat yang sangat tajam stratifikasi sosialnya, sementara Izza datang dari pasangan guru yang kehidupannya relatif mapan. Saat masuk ke lingkungan sekolah, Andrea bertemu dengan guru-guru yang menginspirasi, sedangkan Izza telah mengalami pengalaman buruk di awal masa sekolahnya dan hal itu diperkuat dengan bacaanbacaan kritis tentang dunia pendidikan. Kedua pandangan tersebut ada positif dan negatifnya. Namun demikian, satu hal yang harus ada di lembaga sekolah adalah guru-guru yang mampu menginspirasi murid-muridnya, sehingga sekolah tidak dirasakan sebagai sebuah penjara yang membelenggu.

\section{Saran}

Atas dasar simpulan, maka rumusan saran sebagai berikut. Pertama, bercermin dari kedua buku tersebut, hendaknya semua yang berprofesi guru mulai dari TK sampai perguruan tinggi hendaknya terus berusaha dan belajar untuk menjadi guru yang menginspirasi yang dapat memahami dan menerima murid apa adanya serta dapat memotivasi dan membangkitkan semangat murid untuk keluar dari segala kesulitan hidup. Kedua, bagi para pembuat kebijakan (pemerintah 
melalui Kementerian Pendidikan Nasional hendaknya terus menerus membina para guru sebagai ujung tombak dunia pendidikan, agar semakin banyak guru-guru profesional yang mampu mengemban tugasnya dengan baik.

\section{Pustaka Acuan}

Ahsin, M.Izza. 2007. Dunia Tanpa Sekolah. Read! Publishing House. Bandung.

Buchori, Mochtar. 1998. Komersialisasi Idealisme Bukan Tabu. Majalah Basis No.01-02 Tahun ke 47 Januari - Februari 1998.

Coloroso, Barbara. 2007. Stop Bullying! Memutus Rantai Kekerasan Anak dari Prasekolah hingga SMU. PT. Serambi Ilmu Semesta. Jakarta.

Darmaningtyas. 2005. Pendidikan Rusak-rusakan. LKiS. Yogyakarta.

digilib.uns.ac.id/abstrakpdf

Eriyanto. 2008. Analisis Wacana, Pengantar Analisis Teks Media. LKiS. Yogyakarta.

Freire, Paulo. 2000. Politik Pendidikan. ReaD (Research, Education and Dialogue) bekerja sama dengan Pustaka Pelajar, Yogyakarta.

Henslin, James M. 2007. Sosiologi dengan Pendekatan Membumi Edisi 6 Jilid 2. Penerjemah: Kamanto Sunarto. Erlangga. Jakarta.

Hirata, Andrea. 2007. Laskar Pelangi. Penerbit Bentang. Yogyakarta.

Horton, Paul B.dan Chester L.Hunt. 2006. Sosiologi Jilid 1. Erlangga. Jakarta.

jeperis.wordpress.com

Lawson, Tony, Marsha Jones, Ruth Moores. 2000. Advance Sociology through Diagrams. Oxford University Press.

Mulyana. 2005. Kajian Wacana. Tiara Wacana. Yogyakarta.

Nasution, S. 1995. Sosiologi Pendidikan. Bumi Aksara. Jakarta.

Republika. Ahad. 30 Desember 2007. Halaman B4. Andrea Hirata, Bangga sebagai Melayu Pedalaman.

Rizali, Ahmad, Indra Djati Sidi dan Satria Dharma. 2009. Dari Guru Konvensional Menuju Guru Profesional. PT.Grasindo. Jakarta.

Sindhunata (Editor). 2002. Membuka Masa Depan Anak-anak Kita, Mencari Kurikulum Pendidikan Abad $X X I$. Kanisius. Yogyakarta.

Sugiyanto. 2002. Lembaga Sosial. Global Pustaka Utama. Yogyakarta.

Sunarto, Kamanto. 2000. Pengantar Sosiologi Edisi ke 2. Lembaga Penerbit Fakultas Ekonomi Universitas Indonesia. Jakarta.

Suyanto. 2006. Dinamika Pendidikan Nasional dalam Percaturan Dunia Global. PSAP Muhammadiyah. Jakarta.

Topatimasang, Roem. 1998. Sekolah Itu Candu. Pustaka Pelajar. Yogyakarta.

UNESCO. 2007. Akar Kokoh Pengasuhan dan Pendidikan Anak Usia Dini. Ringkasan Laporan Pemantauan Global PUS 2007. 